DOI: $\underline{10.35619 / \text { iiu.v2i13.361 }}$

Шурин Олена

кандидат педагогічних наук, доцент кафедри професійної освіти, трудового навчання та технологій Рівненського державного гуманітарного університету, м. Рівне, Україна

ORCID: 0000-0002-8804-7860 e-mail: olena.shuryn@rshu.edu.ua

\title{
РЕАЛІЗАЦІЯ ОСОБИСТІСНО ОРІЕНТОВАНОГО ПІДХОДУ У ПРОФЕСІЙНІЙ ПІДГОТОВЦІ МАЙБУТНЬОГО ВЧИТЕЛЯ
}

Анотація. У статті розкрито основні аспекти реалізації особистісно орієнтованого підходу у професійній підготовці майбутнього вчителя. На основі аналізу наукової та психолого-педагогічної літератури виокремлено науковців, які досліджували та впроваджували особистісно орієнтованого підхід у процесі підготовки майбутніх педагогів. Проаналізовано поняття особистісно орієнтований підходу та близьких за змістом понять, зокрема: особистісно орієнтованого навчання, особистісно орієнтованої взаємодії, особистісно орієнтованої освіти. Обгрунтовано особистісно орієнтований підхід як найважливіший психолого-педагогічний принцип, що передбачає врахування своєрідності та індивідуальності особистості майбутнього вчителя; створення умов для самопізнання, самореалізації та саморозвитку особистості студента; систему відносин, за якою кожен студент відчуває себе особистістю і відчуває увагу педагога особисто до нього; спрямування навчально-виховного процесу на кожну окрему особистість 3 визнанням іiі унікальності. Сформульовано головну мету особистісно орієнтованого підходу, яка зводиться до розвитку мислення майбутніх учителів, їх творчого потенціалу, гармонійного формування i всебічного розвитку їх особистості, розкриття неповторної індивідуальності. Визначено важливі ознаки особистісно орієнтованого підходу та педагогічні умови його здійснення.

Ключові слова: особистісно орієнтований підхід, підготовка майбутнього вчителя, навчально-виховний процес, особистісно орієнтоване навчання, педагогічна діяльність.

Постановка проблеми. В умовах сьогодення та сучасних світових тенденцій підготовки педагогічних кадрів перед вищою освітою України постає завдання не лише забезпечення майбутніх учителів необхідними професійними знаннями, уміннями та навичками, але й виховання гармонійного та креативного вчителя, який буде сформований як творча й соціально-активна особистість, здатна до пошуку та реалізації нових ефективних і сучасних способів здійснення навчально-виховного процесу. 


\section{Інноватика у вихованні. Випуск 13.Том 2. 2021.}

Тому пріоритет розвитку особистості майбутнього вчителя реалізовується на засадах особистісно орієнтованого навчання, яке передбачає створення особливих умов навчально-виховної діяльності, створення сприятливого психологічного клімату в навчальному процесі, розвитку пізнавальних, інтелектуальних, творчих потреб і можливостей кожного студента.

Аналіз останніх досліджень 3 проблеми. Основні засади особистісно орієнтованого підходу розкрито в наукових дослідженнях С. І. Архангельского, Г. А. Балла, І. Д. Беха, Є. В. Бондаревської, Л. С. Виготського, І. О. Зимньої, О. О. Леонтьєва, А. К. Маркової, А. І. Підласого, Є. С. Полат, С. Л. Рубінштейна, С. О. Сисоєвої, I. С. Якиманської та ін. Психолого-педагогічні аспекти впровадження особистісно орієнтованого підходу описані в працях О. Є. Антонової, О. А. Дубасенюк, А. Г. Івершинь, Л. Г. Кайдалової, В. Г. Кременя, 3. Н. Курлянд, О. Я. Савченко, І. С. Якиманської, О. В. Ящук та ін.

Мета статті - визначити умови реалізації особистісно орієнтованого підходу у професійній підготовці майбутнього вчителя.

Виклад основного матеріалу дослідження. Застосування в навчально-виховному процесі підготовки майбутніх учителів особистісно орієнтованого підходу передбачає створення психолого-педагогічних умов, які сприятимуть особистісному становленню студентів, розвитку їх професійної та творчої активності, самореалізації в майбутній професійній діяльності.

Поняття «особистісно орієнтований підхід» близьке за змістом до понять «особистісний підхід», «особистісно орієнтована взаємодія», «особистісно орієнтоване навчання», «особистісно орієнтована освіта», тощо.

Згідно зі словником-довідником 3 професійної педагогіки, особистісний підхід визначається як послідовне ставлення педагога до вихованця як до особистості, як до самосвідомого відповідального суб'єкта власного розвитку, як до суб'єкта взаємодії (Словник-довідник 3 професійної педагогіки, 2006, с.124).

Особистісно орієнтована взаємодія передбачає діалогічне спілкування, емпатійне слухання, атмосферу взаємної довіри, відвертості та доброзичливості між учасниками навчально-виховного процесу, знання, розуміння й прийняття викладачем індивідуальних психологічних особливостей студентів.

В основі особистісно орієнтованого навчання закладено визнання індивідуальності, самобутності, самооцінки кожної людини, іiі розвитку як індивіда, наділеного своїм неповторним суб'єктивним досвідом. Мета особистісно орієнтованого навчання полягає у максимальному розвитку студента 3 урахуванням його можливостей і нахилів (Словник-довідник 3 професійної педагогіки, 2006, с.125).

І. А. Зязюн, Л. Г. Кайдалова розглядають особистісно орієнтоване навчання як процес, у якому студент знаходиться в центрі навчання та у якому навчально-пізнавальна діяльність, а не викладання, є провідною у 


\section{Інноватика у вихованні. Випуск 13.Том 2. 2021.}

тандемі викладач-студент (Кайданова, 2008). Особистісно орієнтоване навчання дозволяє реалізуватися кожному студентові, керуючись власними мотивами та інтересами, використовуючи особистісні можливості та здібності, ціннісні орієнтації тощо.

Особистісно орієнтована освіта грунтується на загальнолюдських та особистісних цінностях, з урахуванням потреб самої людини, їі мотивів, здібностей, особистих якостей, життєвих цінностей тощо (Кайданова, 2008).

Зі свого боку, особистісно орієнтований підхід передбачає здійснення педагогічного процесу, спрямованого на кожну окрему особистість 3 визнанням їі унікальності, інтелектуальної і моральної свободи, права на повагу, створення сприятливих умов для розвитку іiі індивідуальних особистісних здібностей i творчого потенціалу (Словник-довідник 3 професійної педагогіки, 2006, с.125).

О. А. Дубасенюк особистісний підхід тлумачить як найважливіший психолого-педагогічний принцип, що передбачає врахування своєрідності індивідуальності особистості майбутнього вчителя, систему відносин, за якою кожен студент відчуває себе особистістю і відчуває увагу педагога особисто до нього. Особистісно орієнтоване навчання, як зазначають О. А. Дубасенюк, О. Я. Савченко - це організація навчання на засадах всебічного врахування індивідуальних потреб і особливостей кожного студента, глибокої поваги до його особистості, ставлення до нього як до відповідального та свідомого суб'єкта учасників навчально-виховної взаємодії. Особистісно орієнтоване навчання покликане забезпечувати індивідуальну самореалізацію майбутніх учителів, розвиток та саморозвиток їх особистісних якостей з урахуванням їх особистісних інтересів та здібностей (Дубасенюк, 2012, с. 15).

О. В. Ящук, спираючись на дослідження Є. В. Бондаревської під поняттям особистісно-орієнтованого підходу розуміє методологічну орієнтацію в педагогічній діяльності, що за допомогою опори на систему взаємопов'язаних понять, ідей та способів дій, що дозволяє забезпечувати й підтримувати процеси самопізнання, самореалізації особистості майбутнього вчителя, розвитку його неповторної індивідуальності. В особистісно-орієнтованому навчанні розвиток й саморозвиток особистості здійснюється на основі виявлення ऑiі індивідуальних особливостей як суб'єкта пізнання й предметної діяльності (Ящук, 2013).

Особистісно орієнтований підхід як методологічну орієнтацію в педагогічній діяльності, яка дозволяє забезпечити і підтримати (за допомогою опори на систему взаємопов'язаних понять, ідей та способів дій) процеси самопізнання, самоекскавації і самореалізації особистості майбутнього вчителя, розвиток його неповторної індивідуальності розглядають Т. В. Раструба та С. С. Горбенко Особистісно орієнтований підхід вміщує в собі процесуальний компонент освіти у його триєдності (навчання, розвиток і виховання) та об'єднує таку систему в єдиний 


\section{Інноватика у вихованні. Випуск 13.Том 2. 2021.}

процес допомоги, підтримки, соціально-педагогічного захисту, розвитку студента, підготовки його до життєтворчості тощо (Раструба, 2018).

При використанні особистісно орієнтованого підходу освітня діяльність вчителя стає індивідуальною, «авторською», проєктування навчальної ситуації у межах певного предмета зорієнтовується на тип психічного розвитку студентів та індивідуальні можливості педагога (Раструба, 2018).

Головною метою особистісно орієнтованого підходу до навчання стає не просто засвоєння знань і формування умінь, а розвиток мислення майбутніх учителів і їх творчого потенціалу (Раструба, 2018); гармонійне формування і всебічний розвиток особистості, повне розкриття іiі творчих сил, вироблення власного «Я», неповторної індивідуальності (Кайдалова, 2008).

До важливих ознак особистісно орієнтованого підходу належить (І. Д. Бех, Л. Г. Кайдалова, О. Я. Савченко) багатоваріантність методик і технологій, уміння організовувати навчання одночасно на різних рівнях складності, зміцнення всіма засобами цінностей емоційного благополуччя, позитивного ставлення до світу, тобто внутрішньої мотивації (Кайдалова, 2008).

Реалізація особистісно орієнтованого підходу передбачає виконання низки педагогічних умов його здійснення, а саме: врахування неповторності кожного студента; визнання неправомірним поділ майбутніх учителів на здібних і нездібних; врахування індивідуальних вікових особливостей студентів; визнання кожного студента особистістю; забезпечення позитивних почуттів від навчання; виховання особистісних здібностей через подолання труднощів; застосування дослідницьких елементів під час особистісного навчання; здійснення навчально-виховної діяльності на засадах людяності, чуйності i тактовності стосовно студентів; розуміння оцінки знань майбутніх учителів як інструмента виховання; сприяння креативності студентів; надання діалогового характеру міжособистісних стосунків між педагога і майбутнього вчителя; (Раструба, 2018); домінування суб'єкт-суб'єктного характеру взаємодії учасників педагогічного процесу; необхідність створення умов для психолого-педагогічної підтримки особистісного становлення студента на етапах його адаптації до навчання й роботи; ідентифікації 3 вимогами професійної діяльності, творчої самореалізації (Ящук, 2013); створення умов для самореалізації особистості, самопізнання за допомогою різних видів діяльності, де студент є суб'єктом діяльності; виявлення творчого потенціалу студентів, його діагностика і формування; використання засобів невербального спілкування за допомогою візуальних образів, символів, використання методів арт-терапії; педагогічне спілкування, при якому педагог виступає як співучасник творчого процесу, створює проблемні ситуації вибору, спонукає робити свій вибір, шукати різні шляхи вирішення проблемних педагогічних ситуацій (Івершинь, 2018); розвиток і саморозвиток особистості як суб'єкта пізнавальної та предметної 


\section{Інноватика у вихованні. Випуск 13.Том 2. 2021.}

діяльності; розвиток здібностей, схильностей, інтересів, ціннісних орієнтацій студентів, беручи до уваги їх суб'єктивний досвід; побудова змісту освіти, засобів й методів навчання 3 можливістю обрання майбутнім учителем предметного матеріалу, його видів та форм; побудова навчального процесу на принципі варіативності (Кайдалова, Якиманська), (Кайдалова, 2008); створення такого розвивального середовища (зміст, організаційні форми, методи, засоби, суб'єкт-суб'єктний характер педагогічної взаємодії), у якому майбутній педагог набуває статусу найвищої цінності навчального процесу i яке сприятиме розвитку інтелектуального, творчого i духовного потенціалу студентів, їх індивідуальності, емоційно-вольових якостей, творчих можливостей, мислення і загальної культури, формуванню здатності до самостійної, активної діяльності, професійного самовизначення, навичок взаємодії із сучасним динамічним ринком праці (Кайдалова, 2008); створення умов для досягнення кожним студентом реально можливого для нього у визначений період рівнів навчальної успішності, самопізнання, самонавчання та самооцінки своїх цілей і можливостей (Кайдалова, 2008).

Висновки i перспективи подальших розвідок. Особистісно орієнтований підхід у здійсненні навчально-виховного процесу передбачає, що центром в означеній діяльності є особистість майбутнього вчителя, а весь освітній процес спрямований на розвиток його продуктивної, творчої професійної і соціокультурної діяльності, розвиток індивідуальності та унікальності майбутніх педагогів, розкритті особистісних можливостей. Особистісно орієнтоване навчання дає можливості: кожному студентові, з урахуванням його здібностей, нахилів, інтересів, цілей та ціннісних орієнтацій, реалізувати себе в пізнавальній та навчальній діяльності: стимулює студента для самопізнання, самовиховання та самовдосконалення.

Перспективу подальших досліджень вбачаємо у впровадженні ефективних технологій здійснення освітнього процесу на засадах особистісно орієнтованого підходу.

\section{СПИСОК ВИКОРИСТАНИХ ДЖЕРЕЛ}

Словник-довідник з професійної педагогіки (2006) / за ред. А. В. Семенової. О.: Пальміра. 221 с.

Кайданова, Л. (2008). Теоретичні та методологічні аспекти особистісно орієнтованого навчання. Педагогіка, психологія та медикобіологічні проблеми фізичного виховання і спорту. № 3. СС. 74-77.

Професійна педагогічна освіта: особистісно орієнтований підхід: монографія. (2012) / за ред. О. А. Дубасенюк. Ж.: вид-во ЖДУ ім.І Франка. 436 с.

Ящук, О. (2013). Психологічні аспекти впровадження особистісноорієнтованого підходу в навчання іноземної мови професійного спрямування. Науково-практична конференція «Новітні освітні 


\section{Інноватика у вихованні. Випуск 13.Том 2. 2021.}

технології»: веб-сайт КПI. URL: http://confesp.fl.kpi.ua/ru/node/1126 [Дата звернення 14.04.21].

Раструба, Т. (2018). Особистісно орієнтований підхід як ключовий принцип організації мистецької освіти учнів загальноосвітніх навчальних закладів України: вимоги сьогодення. Молодий вчений. №1(2). СС.825828.

Івершинь, А. (2018). Роль особистісно-орієнтованої технології навчання у художньому розвитку студентів майбутніх вихователів. Актуальні питання гуманітарних наук. Вип.20, т.1. СС.136-141.

\section{REFERENCES}

Slovnyk-dovidnyk z profesiinoi pedahohiky [Dictionary-reference book on professional pedagogy]. (2006). O.: Palmira. 221 s. [in Ukrainian].

Kaidanova, L. (2008). Teoretychni ta metodolohichni aspekty osobystisno oriientovanoho navchannia. [Theoretical and methodological aspects of personality-oriented learning]. Pedahohika, psykholohiia ta medyko-biolohichni problemy fizychnoho vykhovannia i sportu. 2008. No 3. SS. 74-77. [in Ukrainian].

Profesiina pedahohichna osvita: osobystisno oriientovanyi pidkhid: monohrafiia [Professional pedagogical education: personality-oriented approach: monograph]. (2012). Zh.: vyd-vo ZhDU im.I Franka. 436 s. [in Ukrainian].

Iashchuk, O. (2013). Psykholohichni aspekty vprovadzhennia osobystisnooriientovanoho pidkhodu $\mathrm{v}$ navchannia inozemnoi movy profesiinoho spriamuvannia. [Psychological aspects of implementing a personality-oriented approach to teaching a foreign language for professional purposes]. V: Naukovo-praktychna konferentsiia "Novitni osvitni tekhnolohii": veb-sait KPI. URL: http://confesp.fl.kpi.ua/ru/node/1126 [Data zvernennia 14.04.21). [in Ukrainian].

Rastruba, T. (2018). Osobystisno oriientovanyi pidkhid yak kliuchovyi pryntsyp orhanizatsii mystetskoi osvity uchniv zahalnoosvitnikh navchalnykh zakladiv Ukrainy: vymohy sohodennia. [Personality-oriented approach as a key principle of the organization of art education of students of secondary schools of Ukraine: nowadays requirements]. Molodyi vchenyi. 2018. No 1(2). SS.825828. [in Ukrainian].

Ivershyn, A. (2018). Rol osobystisno-oriientovanoi tekhnolohii navchannia u khudozhnomu rozvytku studentiv maibutnikh vykhovateliv. [The role of personality-oriented learning technology in the artistic development of students of future teachers]. Aktualni pytannia humanitarnykh nauk. 2018. Vyp.20, t.1. SS.136-141. [in Ukrainian]. 


\title{
IMPLEMENTATION OF A PERSONALLY-ORIENTED APPROACH IN THE PROFESSIONAL TRAINING OF THE FUTURE TEACHER
}

\author{
Olena Shuryn \\ Candidate of Pedagogical Sciences, \\ Associate Professor at Vocational Education, Labor Training and \\ Technology Department \\ Rivne State University for the Humanities, \\ Rivne, Ukraine \\ ORCID: 0000-0002-8804-7860 \\ e-mail: olena.shuryn@rshu.edu.ua
}

\begin{abstract}
The article reveals the main aspects of the implementation of personality-oriented approach in the training of future teachers. Based on the analysis of scientific and psychological-pedagogical literature, scientists who were engaged in research and implementation of a personality-oriented approach in the process of training future teachers were singled out. The concepts of personality-oriented approach and similar concepts were analyzed, in particular: personality-oriented learning, personality-oriented interaction, personality-oriented education. The personality-oriented approach is explained as the most important psychological and pedagogical principle, which takes into account the uniqueness of the personality of the future teacher, the system of relations in which each student feels like a person and feels the teacher's attention to him personally; methodological orientation in pedagogical activity, which relies on a system of interconnected concepts, ideas and methods of action, which allows to provide and support the processes of self-knowledge, self-realization of the future teacher, the development of his unique personality. The main purpose of the personality-oriented approach was formulated, which consists in the development of thinking of future teachers, their creative potential, harmonious formation and comprehensive development of their personality, disclosure of unique individuality. Important features of the personality-oriented approach and pedagogical conditions of its implementation are determined, namely: taking into account the uniqueness of each student; implementation of educational activities on the basis of humanity, sensitivity and tact in relation to students; the dominance of the subject-subject nature of the interaction of participants in the pedagogical process; creation of conditions for self-realization of the person, development of creative possibilities of students; providing opportunities for future teachers to realize themselves in various activities; organization of the educational process as a harmonious combination of teaching and education, the disclosure of creative potential and abilities of future teachers, etc.
\end{abstract}

Keywords: personality-oriented approach, training of future teachers, educational process, personality-oriented learning, pedagogical activities.

Стаття надійшла до редакиї̈ 07. 05. 2021 p. 